\section{Tolerance of Controlled Atmosphere Storage of Cut Fraser Fir and Its Respiration Rate in Air}

\author{
Sylvia M. Blankenship and L. Eric Hinesley \\ Department of Horticultural Science, North Carolina State University, \\ Raleigh, NC 27695-7609
}

Additional index words. Christmas trees, postharvest physiology, postharvest handling, Abies fraseri

Abstract. Fraser fir [Abies fraseri (Pursh) Poir.] branches were held at 5C for 4 to 6 weeks in the following atmospheres: $1 \%$ or $3 \% \mathrm{O}_{2}$ in nitrogen; $0 \%, 1 \%, 5 \%, 10 \%$, $\mathbf{2 0 \%}, \mathbf{4 0 \%}$, or $\mathbf{5 0 \%} \mathrm{CO}_{2}$ in air; or air only. Experiments were conducted in two. years during the fall, winter, and early spring. In general, $\mathrm{CO}_{2} \geq 5 \%$ accelerated needle loss. There was considerable tree-to-tree variation in tolerance to elevated $\mathrm{CO}_{2}$. Oxygen at $1 \%$ killed branches, and $3 \% \mathrm{O}_{2}$ showed no benefit compared to air. The initial dark respiration rate at $21 \mathrm{C}$ was about four times higher than at SC. Respiration decreased for $\approx 10$ days and stabilized at $14 \%$ to $20 \%$ of the initial values. Respiration increased exponentially with increasing temperature between 5 and 27C. Short-term controlled or modified atmosphere storage would probably not be useful in improving the postharvest handling of Fraser fir.

Controlled (CA) or modified atmosphere (MA) storage is widely used in the postharvest handling of horticultural crops (Isenberg, 1979; Smock, 1979). Recognized benefits include reduced respiration rates during storage (Kader, 1985a), inhibition of microorganisms (El-Goorani and Sommer, 1981; Spotts 1984), and reduced ethylene biosynthesis and action (Kader, 1985a). Fruits, vegetables, and plants display diverse levels of sensitivity to altered atmospheres (Kader, 1985b). For example, some varieties of rose tolerate up to $60 \% \mathrm{CO}_{2}$ (Joyce and Reid, 1985).

CA or MA storage of ornamentals has been limited and thus far has shown little promise (Eisenburg, 1985). Most of the earlier work was conducted on herbaceous, flowering commodities. Since woody coniferous tissue differs consjderably from cut flowers, it seemed justified to examine the effects of CA or MA storage on this tissue. We also wanted to determine respiration rates of Fraser fir in air, since this information is basic for any storage. work, regardless of atmosphere. Little is known about CA or MA storage of conifers. Behrens (1986) stored unrooted cuttings of 10 conifer species in $3 \% \mathrm{O}_{2}$ and $3 \% \mathrm{CO}_{2}$, with no benefit to rooting after storage, except in Picea glauca (Moench) voss.

Fraser fir is a popular conifer for use either as a cut Christmas tree or greenery during the holiday season. While cut Fraser fir normally exhibits good needle retention, trees

Received for publication 28 Aug. 1989. Paper no. 12329 of the Journal Series of the North Carolina Agricultural Research Service, Ralcigh, NC 276957643. The cost of publishing this paper was defrayed in part by the payment of page charges. Under postal regulations, this paper therefore must be hereby marked advertisement solely to indicate this fact. sometimes experience unacceptable postharvest needle loss. Marketing of Christmas trees is diversifying to include mail order sales. It is often necessary to begin harvest several months before Christmas, which increases the chance for unacceptable needle loss (Mitcham-Butler et al., 1987). Subop1988, 0 = Feb. 1989 . timal storage conditions also increase the risk of premature needle abscission. The present work was undertaken to determine a) if Fraser fir would benefit from short-term reducedO storage, b) if it could tolerate elevated $\mathrm{CO}_{2}$ levels, and c) the respiratory pattern of cut Fraser fir, over time and at various temperatures, as background information for future postharvest handling experiments.

In each of the seven trials, uniform branches of Fraser fir $\approx 0.4 \mathrm{~m}$ long were cut from healthy 15- to 20-year-old nonsheared trees growing near Sparta, N.C., or near Crossnore, N.C. Branches were immediately placed with bases in water, transported to Raleigh, N.C., and placed in a dark $5 \mathrm{C}$ room. Treatments were initiated the next day. Needles were removed from the bottom $0.2 \mathrm{~m}$ of the stem. Six branches (one per tree) were placed in each of six controlled atmosphere cylinders at the beginning of each trial. The same six trees were used in each trial during 198687 , while a second set of six trees was used in 1988-89. Chambers were constructed from PVC cylinders $(74 \mathrm{~cm}$ tall, $15 \mathrm{~cm}$ inside diameter, $9.5 \mathrm{~mm}$ wall thickness). A Plexiglas plate was permanently sealed to the bottom of each cylinder, and-inlet and outlet lines were placed on the sides. The top of each cylinder was lightly coated with vacuum grease and sealed with a 9.5-mm PVC cap. Specific atmospheres were established by using flow meters. The gas atmospheres were bubbled through water to raise the humidity,
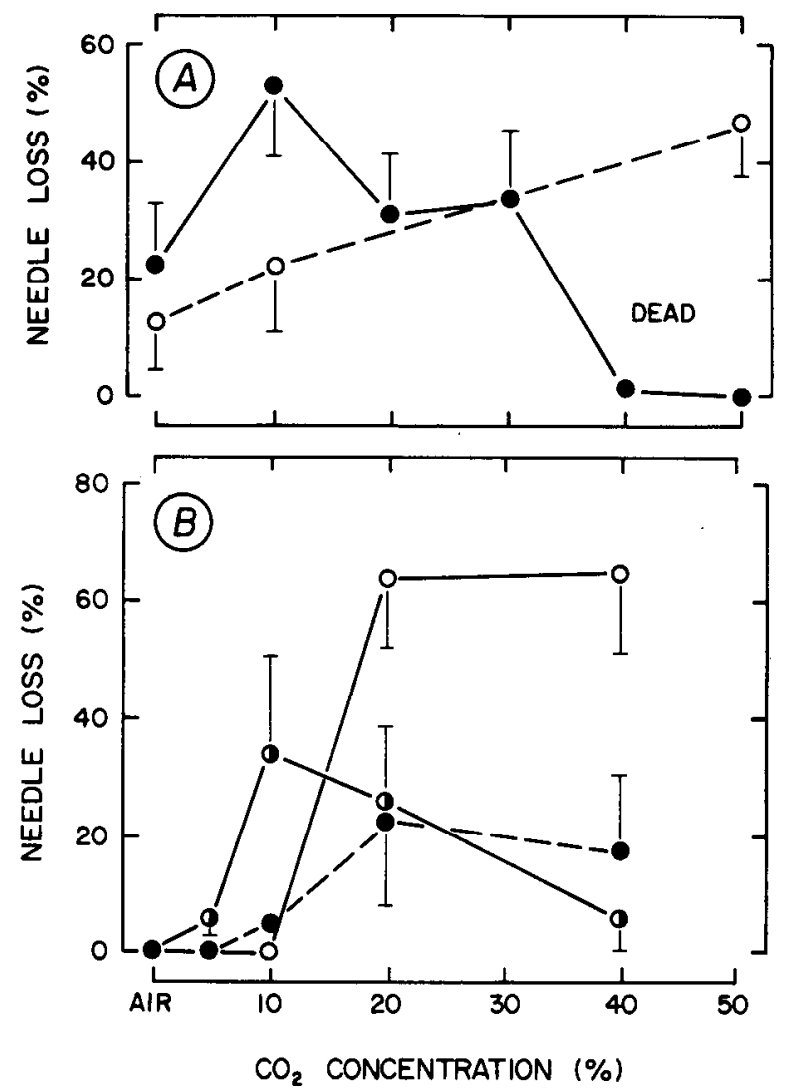

Fig. 1. Effect of harvest date and various $\mathrm{CO}_{2}$ levels on subsequent postharvest needle loss of Fraser fir branches; $\mathrm{n}=$ six trees, vertical bars $=$ SE. (A) Experiments in 1986-87; $O=$ Fall 1986, the mean of two trials; $\bullet=$ Mar. 1987. (B) Experiments in 1988-89; $O=$ Oct. $1988,0=$ Dec. 

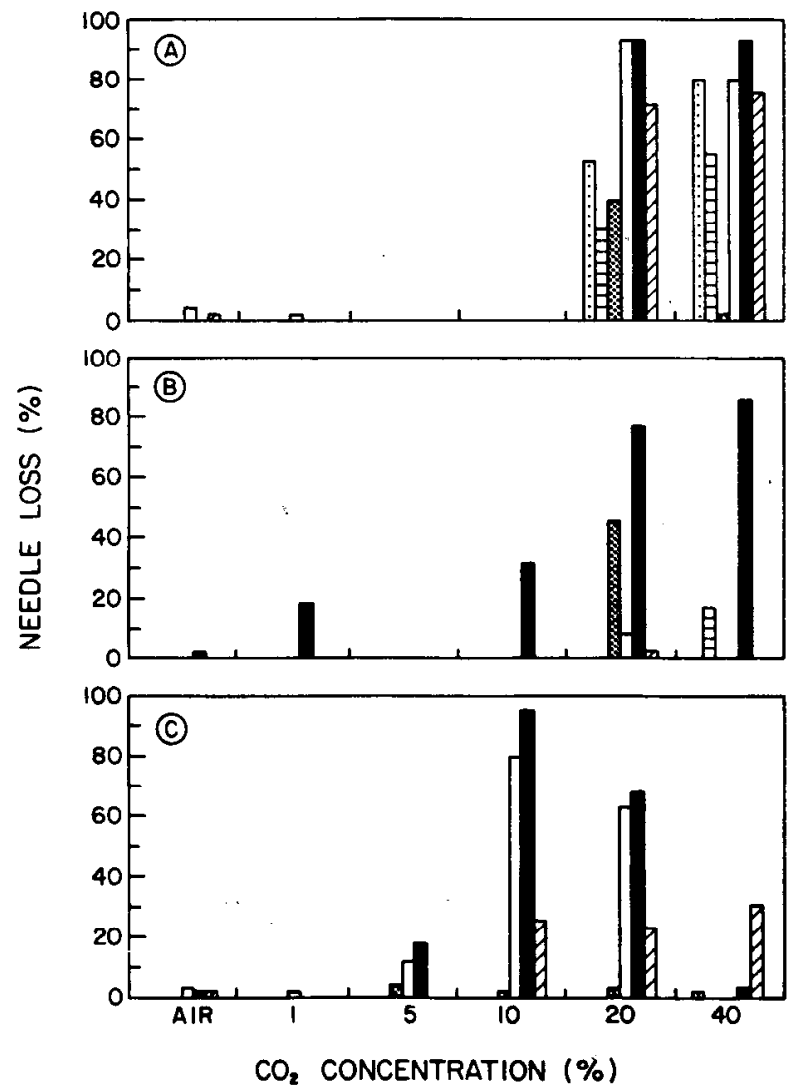

Fig. 2. Postharvest needle loss of individual Fraser fir trees at various harvest times. Trees were stored in $\mathrm{CO}_{2}$ for 6 weeks at $5 \mathrm{C}$, then displayed in air for 2 weeks at $21 \mathrm{C}$ to observe needle loss. Harvest time: (A) Oct. 1988, (B) early Dec. 1988, (C) late Jan. 1989. Where no bar appears, the value was $\leq 2 \%$. Tree numbers: $:=1, \boxminus=2$, $:=3, \square=4, \mathbf{D}=5, \square=6$.

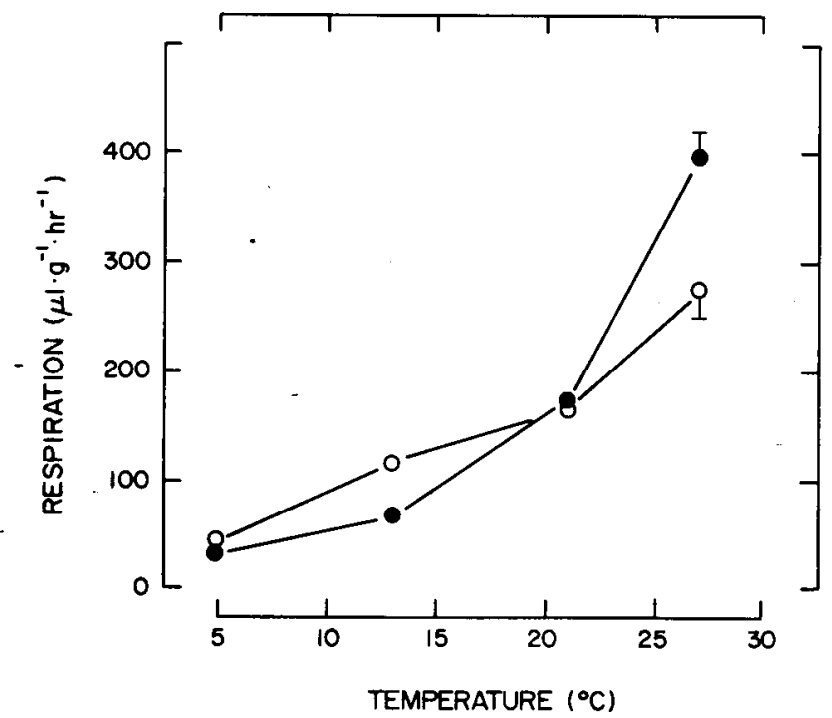

Fig. 3. Initial respiration rate at various temperatures for Fraser fir branches; $n=$ six trees. Vertical bars are SE; others were smaller than symbols. $-=$ Feb. $1989, \mathrm{Y}=7.71(\mathrm{~T})^{1.05}, R^{2}=0.94 .0$ $=$ Dec. 1988, $\mathrm{Y}=2.52(\mathrm{~T})^{1.43}, R^{2}=0.89$.

but it was not determined. Atmospheres were as follows: air; $1 \%, 5 \%, 10 \%, 20 \%, 40 \%$, or $50 \% \mathrm{CO}_{2}$ in air; $1 \%$ or $3 \% \mathrm{O}_{2}$ in nitrogen. Gases flowed at $\approx 50 \mathrm{ml} \cdot \mathrm{min}^{-1}$ from the mixing chambers to the cylinders. Cylinders were kept in a $5 \pm 2 \mathrm{C}$ dark room. Gas composition in the cylinders was regularly monitored by gas chromatography and maintained within $\pm 15 \%$ of the setpoint. Although the experiment was repeated seven times, not all concentrations were in all trials.

After treatment with the various atmospheres, branches were moved to a controlled environment room, placed upright in empty glass jars, and arranged in a completely random design. In 1986-87, the room was at 25C; in 1988-89, it was at $21 \mathrm{C}$. Branches received fluorescent light $16 \mathrm{hr}$ daily
Table 1. Effect of reduced $\mathrm{O}_{2}$ on needle loss of Fraser fir.

\begin{tabular}{lc}
\hline \hline $\begin{array}{l}\text { Oxygen } \\
\text { concn } \\
(\%)\end{array}$ & $\begin{array}{c}\text { Needle drop } \\
\text { after } 2 \text { weeks at } 21 \mathrm{C}^{z} \\
(\%)\end{array}$ \\
\hline 21 (air) & $12.5 \pm 7.9$ \\
3 & $17.8 \pm 7.9$ \\
1 & $1.2 \pm 0.5$ (dead) \\
\hline
\end{tabular}

${ }^{\text {x} A v e r a g e d ~ o v e r ~ s i x ~ t r e e s ~ a n d ~ t w o ~ t r i a l s ~ i n ~ O c t .-~}$ Dec. 1986; first stored at $5 \mathrm{C}$ for 6 weeks.

(photosynthetic photon flux $\approx 40 \mu \mathrm{mol}$. $\mathrm{s}^{-1} \cdot \mathrm{m}^{-2}$ at the top of branches), about the same as a well-lighted room. Foliage loss was monitored several times over 2 weeks by lightly rubbing foliage between the fingers to dislodge abscised needles. Loose needles were collected, dried at $65 \mathrm{C}$, and weighed. At the conclusion of each trial, remaining foliage was removed from each branch, dried, and weighed. Cumulative percent needle loss was then calculated for each branch.

For dark respiration measurements, small Fraser fir branches were placed in 0.9-liter canning jars with rubber septa fitted into the tops. Each branch was $\approx 20 \mathrm{~cm}$ long and consisted of a small second-order lateral with attached third-order laterals. Branches were cut into two or three pieces to fit into the jars. These contained moist paper towels in the bottom at all times and were kept open and at designated temperatures in the dark. Carbon dioxide evolution was measured initially at $5,13,21$, or $27 \mathrm{C}$. Jars were sealed for 2 to $24 \mathrm{hr}$, depending on temperature; then, a l-ml gas sample was withdrawn from the headspace of each jar. Carbon dioxide content of gas samples was determined by gas chromatography at 50C on a Fisher Gas Partitioner equipped with a Porapak Q (Millipore, Waters Division, Taunton, Mass.) column. Branches were further held in the open jars for 30 days at either 5 or $21 \mathrm{C}$.

For branches collected in Fall 1986 (Trials 1 and 2), needle loss was relatively heavy for trees stored in air and increased linearly with increasing $\mathrm{CO}_{2}$ concentration (Fig. 1A). The third trial (data not shown) was initiated in early Dec. 1986 to examine $\mathrm{CO}_{2}$ concentrations between zero and $10 \%$. Only one branch out of 36 lost any needles after a 2week holding period, indicating that trees cut at that time could easily withstand $\mathrm{CO}_{2}$ concentrations up to $10 \%$, with no adverse effects. In the fourth trial, which was initiated in late Mar. 1987, needle loss was heavy at $\mathrm{CO}_{2}$ concentrations up to $30 \%$, and branches subjected to $40 \%$ and $50 \% \mathrm{CO}_{2}$ were killed, but lost few needles, which remained green. Fraser fir is probably quiescent at that time, rather than fully winter dormant, as in December.

During 1988-89 (Trials 5-7), maximum needle loss occurred twice at $20 \% \mathrm{CO}_{2}$ and once at $10 \%$ (Fig. 1B). We cannot explain why needle loss in some trials was not increased by higher concentrations, but rather decreased in several trials.

Following treatment, branches subjected to high $\mathrm{CO}$, dried faster and faded in color 


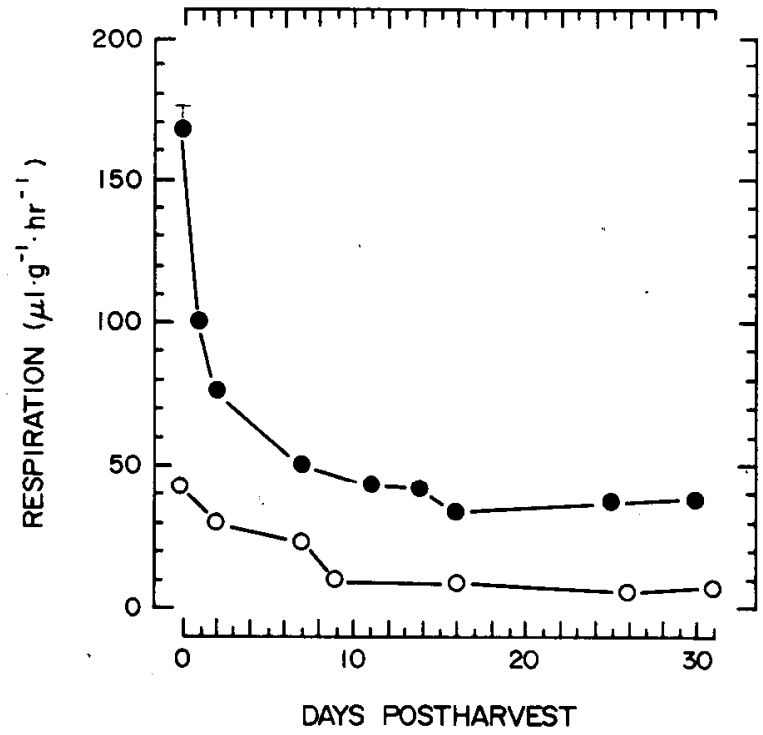

Fig. 4. Respiration rate of cut Fraser fir at 5 or $21 \mathrm{C}$ during 30 days. Branches were harvested in early Dec. 1988; $\mathrm{n}=$ six trees, vertical bars $=\mathrm{SE}$; others were smaller than symbols. $-21 \mathrm{C}, \mathrm{Y}=$ $31.9+135.8(\text { days }+1)^{-1 / 2}, R^{2}=0.95 . O=5 \mathrm{C} ; \mathrm{Y}^{1 / 2}=6.43-0.84(\text { days })^{1 / 2}, R^{2}=0.80$.

more rapidly than controls, even when needles did not abscise. Although branches subjected to $40 \%$ and $50 \% \mathrm{CO}_{2}$ in Apr. 1987 (Trial 4) were killed, they lost very little foliage following storage; perhaps, they died before abscission was completed. Foliage of control branches tended to remain more pliable and softer to the touch following storage and seemed to dry slower than those subjected to high $\mathrm{CO}_{2}$.

Fraser fir branches stored for 6 weeks in $3 \% \mathrm{O}_{2}$ had the same needle loss as those stored in air (Table 1), but $1 \% \quad \mathrm{O}_{2}$ killed branches, while needles adhered strongly and turned brown. Short-term storage in reduced $\mathrm{O}_{2}$ atmospheres did not benefit Fraser fir.

Needle loss by Fraser fir in response to high $\mathrm{CO}_{2}$ varied by season and-among trees (Fig. 2). In general, trees cut in October were more sensitive than dormant trees cut in early December. Some trees were fairly tolerant during December but later became more sensitive. One tree (no. 5) reacted to high $\mathrm{CO}_{2}$ with heavy needle loss in all three trials (Fig. 2). These tree-to-tree differences remain unexplained.

Initial respiration rate increased exponentially with increasing temperature (Fig. 3). For branches collected in Dec. 1988, the pattern was essentially linear up to $21 \mathrm{C}$ and increased at higher temperatures. Respiration of branches collected in early Feb. 1989 accelerated rapidly above 21C. Perhaps branches were less dormant at that time than in December. These results are consistent with observations that high-elevation tree species often show high rates of dark respiration when subjected to high temperatures (Mooney et al., 1964). The results also agree with empirical observations that Fraser fir seedlingsgrow poorly under a 30/26C day/night temperature regime and die after prolonged exposure to constant 30C (Hinesley, 1981). Clearly, low temperatures are best for storage of cut Fraser fir.

Respiration rates decreased when cut branches were held for 30 days at 5 or $21 \mathrm{C}$ (Fig. 4). Initial respiration was $17 q \mu \mathbf{l} \cdot \mathrm{g}^{-1} \cdot \mathbf{h r}^{-1}$ at $21 \mathrm{C}$, decreased $\mathrm{t} \approx 50 \mu \mathrm{l} \cdot \mathrm{g}^{-1} \cdot \mathrm{hr}^{-1}$ over a period of 8 to 10 days, and stabilized thereafter. The initial value at $5 \mathrm{C}$ was $\approx 45$ $\mu \mathrm{l} \cdot \mathrm{g}^{-1} \cdot \mathrm{hr}^{-}$and decreased to an equilibrium value near $1 \mathrm{qu}^{\mathrm{l}} \cdot \mathrm{g}^{-1} \cdot \mathrm{hr}$ by the 10 th day. As with other commodities, refrigeration requirements and attempts at MA packaging would have to take into account these differences in respiration with temperature and the changes that take place as the product ages.

Needle loss was never reduced with elevated $\mathrm{CO}_{2}$; in most cases, it increased (Fig. 1). The safe upper limit for $\mathrm{CO}_{2}$ in a $5 \mathrm{C}$ storage temperature appears to be $5 \%$, but no benefits are derived. Short-term low- $\mathrm{O}_{2}$ storage does not reduce needle loss in Fraser fir. Based on these results, it appears doubtful that CA or MA storage holds much prom- ise in improving postharvest handling of Fraser fir. Because respiration rates are initially high, prompt cooling, perhaps before storage, might be useful in prolonging storage life.

\section{Literature Cited}

Behrens, V. 1986. Cold storage of unrooted coniferous cuttings. Storage temperature and atmosphere. Gartenbauwissenschaft 51:118-125.

Eisenburg, B.A. 1985. A summary of CA requirements, limitations and recommendations for ornamentals, p. 493-505. In: S.M. Blankenship (ed.). Controlled atmospheres for storage and transport of perishable agricultural commodities. Hort. Rpt. 126. North Carolina State Univ., Ra$1 \mathrm{e} \mathrm{i} \mathrm{g} \mathrm{h.}$

El-Goorani, M.A. and N.F. Sommer. 1981. Effects of modified atmospheres on postharvest pathogens of fruits and vegetables. Hort. Rev. 3:412-461.

Hinesley, L.E. 1981. Initial growth of Fraser fir seedlings at different day/night temperatures. For. Sci. 27:545-550.

Isenberg, F.M.R. 1979. Controlled atmosphere storage of vegetables. Hart. Rev. 1:337-394.

Joyce, D.C. and M.S. Reid. 1985. Effect of pathogen-suppressing modified atmospheres on stored cut flowers, p. 185-198. In: S.M. Blankenship (ed.). Controlled atmospheres for storage and transport of perishable agricultural commodities. Hort. Rpt. 126, North Carolina State Univ., Ra$1 \mathrm{e} \mathrm{i} \mathrm{g} \mathrm{h}$

Kader, A.A. 1985a. An overview of the physiological and biochemical basis of CA effects on fresh horticultural crops, p. 1-9. In: S.M. Blankenship (ed.). Controlled atmospheres for storage and transport of perishable agricultural commodities. Hort. Rpt. 126, North Carolina State Univ., Raleigh.

Kader, A.A. 1985b. Modified atmospheres and low-pressure systems during transport and storage, p. 58-64. In: A.A. Kader, R.F. Kasmire, F.G. 'Mitchell, M.S. Reid, N.F. Sommer, and J.F. Thompson (eds.). Postharvest technology of horticultural crops. Spec. Publ. 3311, Univ. of California, Davis.

Mitcham-Butler, E.J., L.E. Hinesley, and D.M. Pharr. 1987. Soluble carbohydrate concentration of Fraser fir foliage and its relationship to postharvest needle retention. J. Amer. Soc. Hort. Sci. 112:672-676.

Mooney, H.A., R.D. Wright, and B.R. Strain. 1964. The gas exchange capacity of plants in relation to vegetation zonation in the White Mountains of California. Amer. Midland Naturalist 72:281-297.

Smock, R.M. 1979. Controlled atmosphere storage of fruits. Hort. Rev. 1:301-336.

Spotts, R.A. 1984. Environmental modification for control of postharvest decay, p. 67-72. In: H.E. Moline (ed.). Postharvest pathology of fruits and vegetables: Postharvest losses in perishable crops. NE-87, Bul. 1914, Univ. of California, Berkeley. 